\title{
Transitional or Transformative Justice? Decolonial Enactments of Adaptation and Resilience Within Palestinian Communities
}

\author{
Devin G. Atallah and Hana R. Masud
}

\begin{abstract}
INTRODUCTION
Transitional justice comprises 'the full range of processes and mechanisms associated with a society's attempts to come to terms with a legacy of largescale past abuses, in order to ensure accountability, serve justice and achieve reconciliation' (United Nations [UN], 2010). It can include criminal trials, truth and fact-finding commissions, reparations and institutional reforms. Across the wide range of processes, transitional justice approaches have tended to focus on peacebuilding in ways that have "prioritized civil-political rights, emerging from a tradition where acts of violence are of greater interest than chronic structural violence and unequal social relations' (Gready and Robins, 2014: 342 ).

Evans (2016: 4) warns that, within this paradigm, issues 'such as social justice, poverty, and land inequalities have tended to be overlooked'. After all, transitional justice is rooted in liberalism and neoliberalism, economic development, universalist human rights frameworks and in colonial hegemonic discourse, which 'sees liberal democracy as its endpoint' (Gready and Robins, 2014: 341). Moreover, transitional justice as a term may be misleading because of the ways that, in periods immediately after a conflict, unjust social systems that uphold structural violence can become further entrenched, even intensified, despite dominant powers and hegemonic discourses declaring that a 'peace' has been made. Indeed, even when attempting more holistic and humanising methods, transitional justice approaches still risk marginalising ongoing structural violence because the paradigm is so deeply set within a backdrop of 'legal and state-based approaches' (Gready and Robins, 2014: 345). In this regard, it is significant that increased context-specific, grassroots approaches to peacebuilding that emphasise complexity, resilience and
\end{abstract}


process over an end goal are emerging (de Coning, 2018; Gready and Robins, 2014; International Center for Transitional Justice, 2019; Ungar, 2020).

Evans (2016) maintains that in conditions marked by structural violence, transformative justice frameworks should be engaged rather than transitional justice (see also Lambourne, Chapter 2). It is in the context of transformative justice that we situate and discuss the concepts of resilience and adaptive peacebuilding. Sharing reflections and stories from our work in communities in Palestine where historical and ongoing structural violence has been set forth through systems marked by settler colonial domination, we argue that confronting these interlocking systems of oppression requires transformative justice frameworks over transitional ones.

\section{WHAT IS TRANSFORMATIVE JUSTICE?}

Transformative justice praxis represents shifts in thinking and practice, collectively re-envisioning and remaking our worlds grounded in the everyday needs and strengths of those most directly impacted by violence and oppression (Brown, 2017). Central to transformative justice is the idea that oppression is at the root of all forms of harm. . . [and] as a practice it therefore aims to address and confront those oppressions on all levels and treats this concept as an integral part to accountability and healing' (Mia Mingus, cited in Kaba and Hassan, 2019: 21). For example, GenerationFIVE is a transformative justice collective based in the United States that engages the leadership of survivors and bystanders of violence in its community prevention and intervention practices, as well as in its public actions and advocacy. GenerationFIVE is involved in cross-movement building to interrupt and heal intergenerational impacts of harm (in particular childhood sexual abuse) on individuals, families and communities. The definition of transformative justice that GenerationFIVE utilises in its multi-systemic work encompasses four overlapping goals:

1. the centrality and focus on the safety, healing and agency of marginalised groups and individuals most vulnerable to surviving harmful systems structured by oppression and violence;

2. the accountability and transformation of those who enact the oppressive systems and cause the harm;

3. the fostering of self-determined community responses and accountability; and

4. the transformation of the community and the broader social conditions and structures that create and perpetuate harm - namely - that create 
and perpetuate systems of oppression, exploitation, domination and statesponsored violence (Kaba and Hassan, 2019: 21).

Through these four interrelated goals, transformative justice praxis responds to the need to fundamentally change the multiple systems that make oppression imaginable. The emphasis is not on reforming existing legal systems and institutions, nor is the focus on restoring state or social structures that have been at the root of violence for so long. In fact, Gready and Robins (2014: 340) explain that, "[t]transformative justice entails a shift in focus from the legal to the social and political, and from the state and institutions to communities and everyday concerns'.

\section{WHY TRANSFORMATIVE JUSTICE IN PALESTINE?}

In this chapter, we argue for transformative justice praxis as necessary for promoting opportunities for multi-systemic resilience and adaptive peacebuilding in Palestine, because of the ways in which interlocking colonial oppressions so unrelentingly shape the daily lives of the Palestinian communities that we work with. Outlining and articulating the depth of conquest and subordination in Palestine is an extremely challenging endeavour and goes well beyond the scope of this chapter. Palestinian decolonial feminist scholar Nadera Shalhoub-Kevorkian (2009) has been working to understand and explicate this complexity of the Israeli Occupation system of control and domination for decades. More recently, Shalhoub-Kevorkian (2016: 1279) has begun to use the term 'Occupation of the Senses' to speak about everyday enactments of colonial rule in Palestine, which "produce social and political separation, present[ing] an explicit aesthetic narrative of control that privileges one group over another'. Shalhoub-Kevorkian (2016: 1279) explains:

By 'occupation of the senses', I refer to technologies that manage language, sight, sound, time and space in the colony; the administration of who acts, who speaks, who gives birth and how, and who walks/moves/drives where and how; and what kind of language, music, smells, marches, colours, cultures and scenes are promoted and inscribed over the spaces, lives and bodies of the colonized.

This analysis of the interlocking colonial oppressions and violence in Palestine overlaps with what Giacaman (2018) has called 'The Wounds Inside'. Giacaman (2018: 16) argues that Palestinian internal, and yet always collective, wounds are "embodied in practice ... not attributable to depressive disease ... which exemplifies the Palestinian condition'. The author goes on to explain the concept of the 'Wounds Inside': 
As surviving civilians of war, Palestinians have experienced internal displacement, forced migration, and the descent of terror and violence to the level of the everyday ordinary, reaching the home front, all of it disordering our lives, producing pain, tragedy, sadness, and misery ... Palestinians are ruled not only with brute force, but also with ambiguity, uncertainty, insecurity, loss of dignity, and deliberate humiliation, all important consequences of chronic war that need acknowledgment and not merely as a matter of physical survival worthy of assistance and support.

(Giacaman, 2018: 16)

Grounded in these understandings of the complexity of violence and oppression in Palestine, in this chapter we engage transformative justice frameworks when exploring intergenerational and everyday decolonial enactments of resilience and adaptation. In doing so, we highlight the importance of the narratives and protagonisms of Palestinian communities directly impacted by structural violence towards becoming involved in creating counter-discourses, rehumanising relationships and generating deep-rooted transformations rather than collectively seeking a specific end goal where a state of peace or security is restored.

Following this line of thinking, in this chapter (which has several synergies with the arguments made by Lykes et al., Chapter 9), we share stories and reflections on critical resources and processes related to counter-narratives and counter-practices that Palestinians wage as powerful enactments of their humanity. In fact, even in writing this chapter, we have attempted to engage transformative justice praxis, which emphasises the importance of emergent strategies (Brown, 2017) and counter-stories (Wynter and McKittrick, 2015) to draw out frameworks and practices that rise 'from below' (Dutta, 2018). These are our 'theories in the flesh' (Fernández, 2018; emphasis in original). Throughout this chapter, we thus share our reflections and counter-stories as entangled knowledges rooted in our own bodies and intergenerational, Indigenous village legacies and lands.

\section{THEORISING FROM THE FLESH: INDIGENOUS VOICES RISING IN OUR WRITING OF THIS CHAPTER}

Who are we as the authors of this chapter? We (Devin and Hana) are two differently positioned Palestinian psychologists, researchers, activists, healers and organisers. I (Devin) am a third-generation Palestinian, based in Boston as an assistant professor at a public university. I am of mixed Indigenous and settler ancestry - I am coloniser and colonised. My father was born in Chile into a Palestinian diasporic community in Santiago. My grandfather was 
a refugee from a village near Bethlehem, Palestine, who immigrated to Chile after the Nakba ('disaster' in Arabic) of 1948 when our Indigenous lands were colonised. My mother is White American from a family lineage of European descendent settlers/colonisers to Hawai'i.

I (Hana) am a postdoctoral research fellow working with Devin's research team. I was born and raised in the West Bank in a village near Ramallah. I moved to Chicago for a doctoral programme after completing my master's degree at a university in Palestine. As the Palestinian poet Mahmoud Darwish says, 'I am from there', from the active uprooting of our people. He writes:

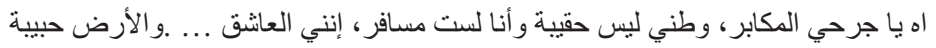

\section{English translation:}

Oh my prideful wound, my homeland is not a suitcase, and I am not a traveler, I am the lover ... and land is my sweetheart...

As Indigenous peoples and members of colonised communities in struggle, the languages of imagination that we voice in this chapter are vital for our understanding and pursuit of transformative justice in our communities. We refuse to write about our colonised geographies in a traditional 'Whitestream' academic analysis, or by simply presenting case examples in the 'real' world. We cannot write a chapter with theory and case examples about our peoples without centring the dreams and wounds that shape our visions for transformative justice. This dream writing and radical reflecting that we practise, even in the writing of this chapter, aims towards explicitly and collectively articulating the just futures that we are struggling to work into reality. And we are not alone. Dream writing and theorising from the flesh are central parts of transformative justice praxis, because '[i]magination is one of the spoils of colonialism, which in many ways is claiming who gets to imagine the future for a given geography' (Brown, 2017: 163).

We thus arrived at the emergent understandings shared in this chapter by talking, laughing and crying together over almost daily face-to-face video conference meetings, email exchanges, text messages and phone conversations during the current period of social distancing due to COVID-19. We often recorded our conversations, asked critical questions to one another and practised radical listening and storytelling. We accompanied each other in what we came to call our transformative justice 'Dream Practice'. During these decolonial dialogues, examples of questions that we asked one another included: What are your dreams for Palestine? What does love and justice look like to you in Palestine? How do you imagine transformative justice contributing to 'adaptative peacebuilding' (de Coning, 2018)? Where do you see this in our decolonial praxis in Palestine? Where does your decolonial praxis come from? 
What are the 'Wounds Inside' that guide you towards the work you know is needed from the depth of your own flesh and family? Where is your wholeness dishonoured as you engage in this work? What do you find yourself continuing to explain to others about Palestinian resilience? What nuances and complexities do you yourself often overlook? What are the rememberings, relations and structures that we need to create and hold to heal ourselves and our communities?

Through this writing process, our 'dream practice', we arrived at the following perspectives and counter-stories that we have decided to incorporate into this chapter. We strive to 'do justice' in our theorisations and examples of the need for transformative justice in Palestine in ways that do not underestimate the devastating uprooting and displacement of our peoples. Like the olive tree, connecting the roots with the branches across exile and generations of dispossession, we seek to be a transformative branch, in our flesh and in our words, in our writings and in our wounds. We invite readers of this chapter to sit with us under this tree, below our intergenerational branches, as we would invite you if we were together, in Palestine.

\section{SELF-DETERMINATION OF COLONISED COMMUNITIES: ASSERTING OUR SOVEREIGNTY WITH DECOLONIAL ATTITUDE AND UNAFRAID REPLANTING}

Across our research and clinical community psychology praxis in Palestine, we have come to understand that one of the foundational keys for resilience overlaps with a crucial difference between transformative justice and transitional justice. The pivotal concept here is self-determination (Atallah, 2017, 2019; Atallah and Ungar, 2020; Masud, 2019). In contrast to transitional justice, transformative justice, according to Dixon (2020), is reliant on the concepts of self-determination and accountability. In the author's words, "violence and oppression break community ties and breed fear and distrust ... the work to create safety is to build meaningful, accountable relationships within our neighborhoods and communities' (Dixon, 2020: 17).

I (Hana) see transformative justice in Palestine as a pathway towards making my ancestors proud. I grow myself, and I theorise resilience guided by my family trees, walking the branches with great precarity and courage. I am inspired by the footsteps of my father, Abu Abdallah, by his stories that have guided me since I was a child. He would always tell me how the Palestinian Liberation struggle was a village-to-village journey. 'Each village at a time', he would say. One village, one model. Another village, another model. As a village, we have to be the model we need, and other communities and 
other villages will follow in their own ways. My father would tell me: 'If you don't go plant olive trees right next to the colony, right next to the settlers, all will be lost. You go plant, even when you know the trees are at risk of being burnt, of being sprayed with chemicals by the colonisers who seek to do violence to our lands and trees at every step of the way. But still, you go, they uproot, and you plant again'. In this way, my father taught me to prioritise, to centre the praxis of replanting and reclaiming the land together (see Figure 10.1). This is decolonial attitude. This is unafraid replanting.

Central to our (Devin and Hana's) emerging transformative justice praxis in Palestine is uplifting self-determination in our Palestinian communities/bodies in the margins as Indigenous peoples living and dying under settler colonialism. This uplifting requires decolonial attitude and unafraid replanting. And these processes directly link our own transformative justice praxis with the praxes of other Indigenous peoples transnationally. For example, Huntley (2015), a transformative justice practitioner of mixed Indigenous and

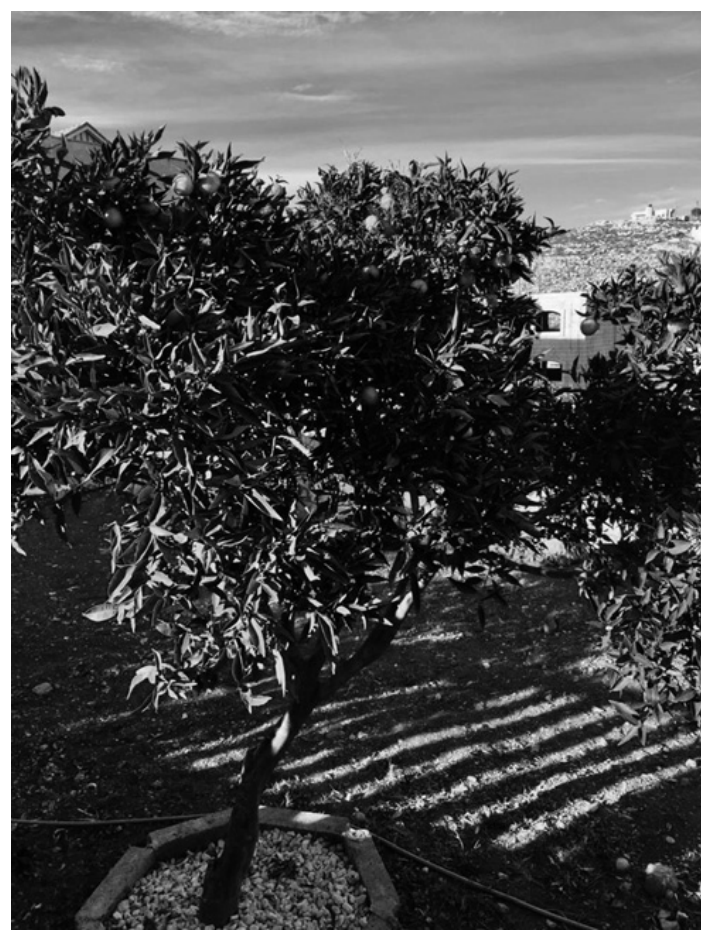

FIGURE 10.1 Image of an orange tree that I (Hana) planted as a child in my home.

Photo by the author. 
settler ancestry from Canada, focuses on investigating and creating films and databases, and supporting collective expressions of grief, resistance and healing related to missing and murdered Indigenous women and girls, trans and Two-Spirit people (MMIWG2S). In her transformative justice work, Huntley underlines the importance of Indigenous communities coming together to listen, learn, love and honour the memory of $\mathrm{MMIWG}_{2} \mathrm{~S}$. Central to their praxis is making sure that critical information about the perpetration of violence is 'controlled by the community and accessible to the community and for the community - not locked away in a government database' (Huntley, 2020: 57).

Huntley (2020: 57) maintains that transformative justice praxis is an assertion of our sovereignty as Indigenous peoples. She explains that ' $[w]$ hat distinguished us for a long time and still distinguishes us from other people who do this work was the understanding of settler colonialism as the inherent root of the violence' (Huntey, 2015: 57). Furthermore, she describes her transformative justice collective that she co-leads as working to directly challenge 'death by colonialism'; and underlines that in the context of this work, 'we understand that there can be no solution outside of completely dismantling the settler colonial state' (Huntley, 2015: 58).

I (Devin) remember first feeling connected to 'decolonial attitude' in key moments when I looked deep into the eyes of my paternal grandparents, my beloved grandmother Mariam and grandfather Jamil in Chile. I remember marching as a youth in protests with my grandmother Mariam as she waved the Palestinian flag in the streets of Santiago de Chile. Even further back, as a four-year-old child, I remember sitting under fruit trees in our family's garden with my grandfather Jamil, noticing his calloused hands, the bullet wounds up and down his leg - wounds from anti-colonial wars. I remember his stories of our village in Palestine. And how the scars in his skin expressed a certain tenderness coated with underlying and explosive rage. As the Palestinian poet in Diaspora Mandy Shunuarah (2019: 57) asks: 'I wonder if coming from a place so battered with conflict caused my family to carry strife in our bones? To wear struggle like armor because it carries the scent of home.' This is decolonial attitude - to wear struggle like armour not simply to protect or to heal, but to stay elevated in the long journey home.

If we rely on our institutions or governments, which are all set within a backdrop of colonial relations, then we are at risk of generating solutions to the problems of structural racism, settler colonialism and coloniality in ways that only mask the violence and turn it into new shapes. As Ahmed (2012: 143) explains, 'solutions to problems can create new problems'. When organisations uphold their existing colonially structured principles and neoliberal goals of 
power for power's sake, productivity, profit, utility, 'good' public relations and related value systems that are deeply built into institutional life, then 'practical solutions' to these problems conceal structural racism in new ways. In this context, Ahmed (2012: 143) goes further and states: 'I want to make a stronger argument here: solutions to problems are the problems given new form'.

In this light, self-determination and decolonial attitude can be critical elements to antiracist transformative justice praxis because of the perilous complexity and risk of continuing structural violence even when working against oppression. In fact, at its core, transformative justice cannot be about expanding the powers and resources of the institutions, the non-governmental organisations (NGOs), the governments or the nation-states that wall our lives as Palestinians. This includes a wide range of institutional and governing bodies, including (but not limited to): Israel, the United States, Iran, Great Britain, Qatar, Jordan, Egypt, the European Union, the UN, the coming and going of waves of international NGOs or even the quasi-governing parties of the 'Palestinian Authority' or 'Hamas'. We question the transformative possibilities of any and all institutions and efforts in Palestine that do not start at the beginning and end with rigorous accountability and the self-determination of our communities. Period. Palestinians are living in perhaps the 'world's largest prison' (Holmes and Balousha, 2019) (see Figure 10.2). The stakes are too high for solutions to keep concealing the intersectional, structural oppressions in Palestine in new ways. Whenever a governing party/institution/NGO/nation-state steps in to promote

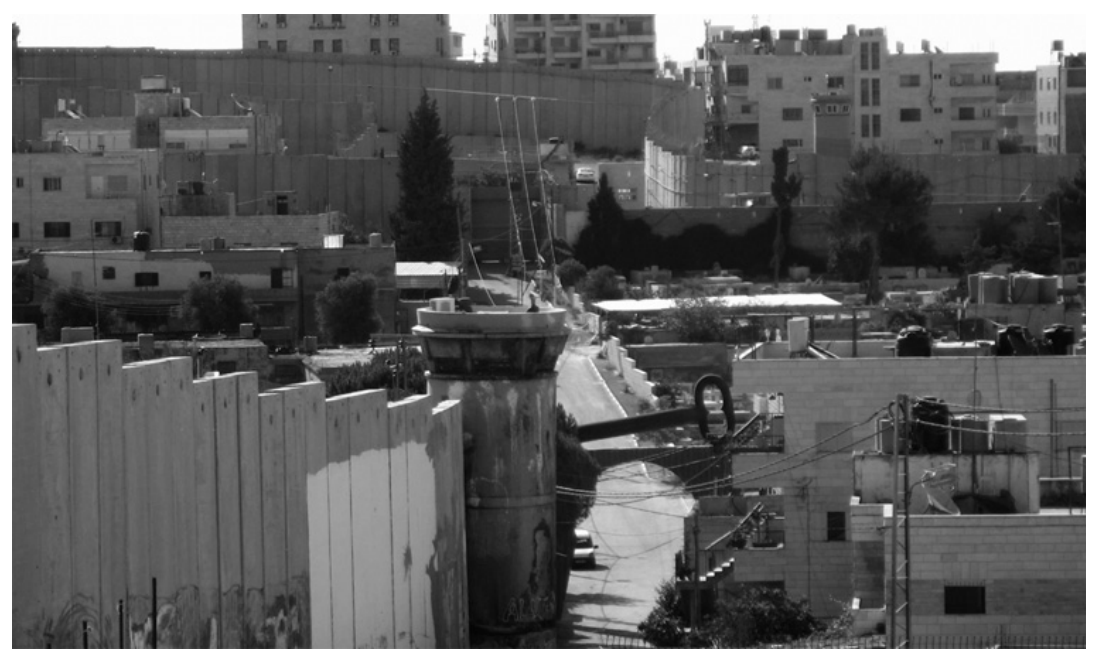

FIGURE 10.2 Israeli wall enclosing a community in the West Bank. Photo by the author. 
'security', 'peace' or 'prosperity' for Palestinians, we are highly suspicious of their solutions and their promises of delivering 'safety' and 'freedom' for our peoples.

In our work under conditions of such intense precarity and oppression, we have learned that meaningful transformations happen at the 'speed of trust' (Brown, 2017). Trust is one of the most precious, and yet least accessible resources available in Palestinian communities at this point in time. Therefore, our second series of counter-stories and perspectives of decolonial adaptation and resilience in this chapter focuses on the importance of creating critical connections (Brown, 2017) within our coalitions, grounded in Indigenous knowledges and courageous and trusting relations, as the heart of our transformative justice praxis.

\section{RADICAL COALITIONS FOR TRANSFORMATIVE JUSTICE: STRENGTHENING OUR CONNECTIONS AND CAPACITIES TO STRUGGLE (WITH AND FOR EACH OTHER)}

Rather than entrusting the work of transformative justice to governments or neoliberal institutions, I (Devin) have learned to focus on co-building communities of resistance and resilience grounded in Palestinian refugee camps through generative creative coalitions in collaboration with marginalised communities (Atallah, 2021; Atallah and Dutta, 2021). One such refugee camp community is directly adjacent to my Indigenous village - the valley in which my paternal grandparents' roots grow deep down into time immemorial where my grandfather Jamil was born. Over the past two years, I have organised and co-led an initiative that supports a local Community Health Worker (CHW) programme in this refugee camp (which will remain anonymous to protect privacy).

At the beginning of the development of this CHW programme two years ago, I focused on providing trainings, supervisions and evaluation research that aimed at supporting the nascent initiative in increasing its capacity to address issues related to trauma and oppression in the patients/community members that the programme serves. Those involved in the programme (the CHWs) are all young people (eighteen to twenty-five years old) who are from the same refugee camp. They work in pairs, providing home visiting services to members of their community (sometimes even to members of their own families) and supporting patients suffering from diabetes, hypertension and other health issues in the camp.

However, more than focusing on physical illness, the CHWs are often a primary social accompaniment for their patients and their families who are suffering from chronic illnesses and have been failed by the health care systems (Israeli, Palestinian Authority, NGOs and UN health systems) - and 
by the interlocking oppressions associated with living in poverty as a Palestinian refugee under the colonial Israeli Occupation system. For example, in a community-based participatory evaluation study that I completed with colleagues and the CHWs themselves (Atallah et al., 2019), one of the CHWs shared how his work often focused less on direct physical health concerns and more on outreach to isolated community members who face many of the same challenges that he himself struggles to overcome:

I met a guy, he was 18 and just released from prison. He didn't want to talk to anyone, he was very isolated. He only talked to his mother, but no one else. So, his doctor told me, 'there's a guy, and you might be able to help him because you went to prison yourself. So, I talked to him the first time and I saw that he was isolated ... I kept meeting with him and talking with him, and I focused on helping him be a part of the community and to talk to people more. And after that, his situation got better ... and he's much better off now.

$$
\text { (cited in Atallah et al., 2019) }
$$

Providing social accompaniment to their patients and families, for these CHWs, means working on the frontlines of intergenerational and continual colonial oppression. The CHWs are obligated to hold a profound weight of colonial trauma with their fellow community members and families. This weight accumulates with each home visit, every day. There is no escape from this totality, from the colonial conditions deeply structured into daily life. During weekly healing circles for the CHWs that I have helped to organise, frequent sentiments that were shared early on in the process included CHWs expressing concerns such as 'my body feels heavy' or 'I'm having serious trouble sleeping'. Narratives of being overwhelmed surfaced, such as: 'I stayed and listened for more than an extra hour to a family during my home visit today because one of their children was just arrested last night. When I left their house, you know, I felt so angry and sad - my brother is also in prison'.

These experiences, and more, lead me to focus on this second core theme of transformative justice that we are emphasising in this chapter - one that harnesses the key resource of co-building radical coalitions as vehicles to be able to practise and live into justice and healing more deeply with impacted communities on the ground. Beginning in the summer of 2019, I started coorganising and co-building an Indigenous Palestinian collective as a radical space for decolonial, transformative justice praxis in Palestine to grow and support the CHWs. This shift was nurtured and supported by my co-author.

In June 2019, we were already working together in a variety of forms, including our co-organising of a decolonial racial justice pre-conference 
event in Chicago for the Society of Community Research and Action (SCRA). Soon after the SCRA conference, in August 2019, we launched together our new initiative in Palestine within the refugee camp community for the CHW programme. We call this new initiative the 'Palestinian Resilience Research Collaborative' (RRC). In a full-day retreat in the refugee camp, our RRC was realised as an assertion of our sovereignty as Indigenous peoples with the vision that we could become the systems that we need. We gathered together at the CHW programme in the refugee camp and established our coalition, focusing on relationships and setting the soil to be able to work towards realising more radical dreams.

In fact, we know, from our decolonial racial justice work, that, within transformative justice praxis, the most valuable resources are not grants or gold, profits or professionalism, high educational degrees or prestigious governmental or private sector positions. The most valuable resources are: time, trust, radical love, remembrance, perseverance, planfulness, playfulness, nuanced political analyses, reflexive and intersectional thinking, decolonial attitude, deep empathy, delicious and nourishing foods and rigorous emotion work - all practised in creative coalitions of people rooted in place and purpose. This coalitional, transformative justice work requires time and labours of people with radical awareness and desire to address cycles of harm, while strengthening together capacities to love and to struggle.

We organised our RRC inspired by these principles. However, identifying what matters and what 'should' work is the easy part. Living into these principles and strategies is the hard part. Even in the initial organising stage of building our coalition, we noticed how challenging it was to align our efforts in the RRC with our principles. In hindsight, we made many mistakes, even at this beginning stage. For example, a significant challenge that emerged for us on the RRC was related to how we originally organised our coalition. At the beginning, I (Devin) reached out to each potential member through a proxy. By 'proxy', I mean someone who has more accountability than I do with the broader community that I am focusing on directly impacting. I made the choice to rely on proxies, rather than using my own efforts to engage in grassroots organising in the camp. I reached out to a few key community members and asked them, as proxies, to refer potential RRC members to me. I relied on proxies because of my lack of daily community participation on the ground - I live thousands of miles away in Boston. I also relied on proxies because of my lack of fluency with the Arabic language, and my dearth of genuinely accountable and interdependent relationships with the local refugee camp community. Therefore, I leaned on the proxies as a way to gain this interdependency. I hoped, once our RRC was built, that we could eventually 
establish high levels of accountability in the broader community. I have since learned that this represents a mistake. I now know that, if I rely on proxies rather than doing the hard and time-consuming work of grassroots organising myself, then accountability moves further and further away on the spectrum.

In this failure, however, also resides a small victory. Problems related to the proxy model within our original development led us as the RRC to the opportunity of exploring with one another what accountability in our relations and structures could look like. These are the conversations and struggles that we are now working through. And this is exactly where we need to be - because a core dimension of transformative justice is about (re) 'imagining and building the structures that we want to see replace the ones we are dismantling today' (Shank, 2020: 27). The RRC is now negotiating tensions between, on one hand, building our coalition within a mainstream resilience framework in the psychology, social work, NGO, neoliberal human service worlds as business as usual; and, on the other hand, working towards engaging decolonial, transformative justice praxis within our coalition and beyond.

In this journey, we (Devin and Hana) have learned that one of the most meaningful elements of transformative justice praxis comes from codeveloping 'the capacity to struggle with each other' (Shank, 2020: 39). In order to be able to increase our capacity to struggle for each other against colonialism, we have to be able to struggle with each other in our everyday work and relationships. Committing to, and continuing, the parallel practice of developing our capacities to struggle with and for each other, as a group of diverse Palestinians on the RRC or within the CHW programme as a whole, is an incredibly radical action itself. Several of the RRC members reflected on this during a recent self-evaluation of our coalition. One of the RRC members voiced:

Over all my years working as a psychologist in Palestine, I have never been in an affinity space with only Palestinians in my work. In fact, often, I am the only Palestinian - with many Norwegians, French, American or Israeli professions, for example, where they are the ones leading, designing, and studying, and supervising our work for my communities. Being on this team, as a Palestinian, in this co-created space, this, in and of itself, feels so different. So necessary.

Furthermore, we (Devin and Hana) want to highlight that developing our capacities to struggle emerged as a necessity. At times, in deeply frustrating ways, complex drama has emerged within the CHW programme itself. Part of transformative justice frameworks includes the understanding that 'trauma leads to drama' in communities as much as in individuals (Shervington, 2018). 
Therefore, in response to these types of concerns, the RRC shifted the understanding of our role from primarily one of developing a manual for the CHW programme towards, instead, beginning to focus more on supporting the CHWs in their own healing and relating, on their own knowing and loving one another with accountability.

A powerful example of this was our initiative to read Paulo Freire's Pedagogy of the Oppressed with the CHWs chapter by chapter in Arabic. Each week in circle discussions, we invited the CHWs to read through the book collectively. This was a critical step in changing the terms of struggle - from inward relational drama on the team to building decolonial insights and owning them. In reading this book in circle together each week with the CHWs, one chapter at a time, stories of refusal of the CHWs took shape, and also stories of guilt and shame, all shared in an emerging and strengthening transformative justice practice space marked by love, trust and transparency. This practice space emergent in the CHW team required the members of the RRC to begin to grow our awareness and our practising of accountability with each other in a parallel process with the CHWs. Even at the small scale of this community praxis in the refugee camp, we do not underestimate our impact as we move with intentionality in our choices and in our relations. As Grace Lee Boggs reminds us, 'transform yourself to transform the world' (cited in Brown, 2017: 53).

We have come to realise that it is in, and through, these relational struggles - how we try to call ourselves into accountability to address, measure and hold ourselves to higher standards - that the choices we make align with the person we want to be in the world' (Long, 2020: 212). As an expression of this alignment, we organised dialogues during the summer of 2020 through the RRC between the Palestinian CHWs in the West Bank refugee camp and African American activists involved in Black Lives Matter (BLM) movements in the United States with whom we work in coalition in Boston and Chicago respectively. An important detail is that the CHWs themselves, during their weekly supervision healing circles, were the ones who asked for this exchange of antiracist knowledges. They were watching the uprisings of Black Americans and their allies in the United States, and the CHWs reached out to us in the RRC, asking to expand their own understandings and share resources for survival and liberation against racialised structural violence from the United States to Palestine.

We were honoured to help make this happen. As the Black freedom fighter Steve Biko (1978: 68) so powerfully wrote in the context of the struggle against South African Apartheid: the heart of this kind of thinking is the realisation by 
the blacks that the most potent weapon in the hands of the oppressor is the mind of the oppressed'. Guided by the life and example of Biko, we understand that, when we, as colonised communities, fail to organise our minds as much as we organise in the streets, we end up continuing cycles of violence and perpetuating harm ourselves, often even directly against one another in our own families and communities. As Dixon (2020: 207) envisions, 'I desire that we have stronger systems and practices that don't involve us quietly swallowing other people's anger, hurt, trauma, and pain'. This leads us to our third and final theme of transformative justice in Palestine: centring our own healing journeys, collectively resetting our wings.

\title{
RESETTING OUR WINGS: EVERYDAY ENACTMENTS OF OUR HUMANITY AND RADICAL LOVE
}

\author{
we know that \\ if the horses can't gallop \\ if the streets break our skull \\ our invisible hurt our lull \\ we will no longer see the stop signs \\ we will no longer know the low tides \\ we will no longer feel the indifference \\ of the wind \\ we will reset our wings.
}

Handal (2019: 100)

An important part of decolonial resilience is our persistence in continually adapting by collectively resetting our wings. We do not underestimate the way the constant accumulation of suffering stacks over time, space and generations in our Palestinian communities, creating conditions marked by allencompassing trauma (Atallah, 2017). In the face of this totality of trauma, it is our embodied enactments of our humanity as Palestinians that are most protective and liberating. These embodied enactments of our humanity are critical components of our collective movements towards life. They cut across all ecological levels - even when our enactments are incredibly mundane or deeply (inter)personal - and they are always systemic and political. Condemned to 'social death', whenever we enact 'the continuation of life in that we too go to work and school, feed our families, speak our own language - is a reminder of radical equality ... Israeli distribution of the 
sensible seeks to define Palestinians as criminals in every interaction, [yet] Palestinians reject such imposed definitions by performing their fully human subjectivities' (Shalhoub-Kevorkian, 2016: 1285).

Interrelated dimensions of colonial violence reduce Palestinians into 'nobodies' (Da Silva, 2009). Therefore, when we as Palestinians perform our fully human subjectivities, we emerge as powerful decolonial enactments of resilience and adaptation through embodied means. Often, these decolonial enactments are not a choice but a necessity. This is true in Palestine and elsewhere in racialised and colonised communities that are actively rising/transforming. As Dixon (2020: 19) writes about her transformative justice work in Black and Brown communities in the United States facing police brutality: 'We just knew we needed to build new structures for our ultimate survival'.

As racialised and colonised peoples transnationally, we are obligated to struggle to return to our bodies and to rehumanise ourselves in our everyday acts and relations as critical enactments of resilience, adaptation and survival 'peacebuilding' that puts our shattered pieces back into a whole. As ShalhoubKevorkian (2016: 1285) reminds us, Palestinians 'cannot simply appeal to their shared humanity (which the coloniser will reject), but rather are forced to constantly enact their humanity in the face of denials'. Persevering in the constant enactment of one's humanity - continually putting our shattered pieces back into a whole - brings continual pain, trauma and more suffering. Decolonial healing - collectively resetting our wings to keep flying despite the destructive power of the colonial winds - becomes a critical key for adaptive peacebuilding.

What keeps me (Hana) flying? Flying despite the weight of the pain? It is my determination despite the messy, complicated, hurtful relationships: the never-ending emotion work. Honestly, my pain is too much for me. I know that no one can take it. Only my collective self keeps me strong. It's all the women. It's all the people that will come after me. It's me, realising that I'm not alone. With this at heart, I can struggle. Knowing that we, all Palestinian women, are all going to feel it, even when we will all feel it differently. Because at its centre, it is collective pain and collective self. That is why I feel the deepest hurt when I am cast outside the herd. My grandparents were shepherds. Bedouins, nomads following light, life and continual movement. Imagining my mom, my grandparents, moving with their animals in our mountains and villages, finding the rhythm to keep everybody and every(living)thing alive. This is my legacy. This is my path. When I am cast outside of my village, because of the Israeli Occupation and because of the patriarchy within my own family, this is the most painful. How do I find the path again? Finding the rhythm? Even when it's healthy to step outside, when I need to 
find shelter, safety and strength away from my village. Still, it's lonely. Still, it's painful.

As Dixon (2O20: 21) highlights, "we are invited to practice community safety skills with one of our most precious resources: our lives. In a world that is already trying to kill us with a multitude of oppressive strategies, we must be deliberate and vigilant in honoring where we each are in our journeys'. Where am I (Hana) in this journey? I am fighting for love, with my life on the line. I dream for love, and I fight for the love that completes me and my people love that brings wholeness. Sometimes that love is not accepted, or that love is arrested, locked up, murdered or denied. Yes, it's love that we fight for. Radical love. As Cornel West $(2018)^{1}$ so powerfully expressed when speaking at the W.E.B. Du Bois Medal Ceremony in support of Colin Kaepernick, an African American activist standing up for racial equity in US contexts: 'Justice is what love looks like in public'.

This radical love, public and activist focused love, is extremely messy, complicated and confusing. We need to have courage, most of all courage to be vulnerable in private and in public. There is no easy journey home for the colonised. There is no map, no manual, no intervention plan or conceptual framework that can guide us. For colonised women, there are even fewer options for our journeys home, our journeys towards wholeness. Our private and public lives are even more policed. I'm so tired of being controlled, cold, broken and shattered. I realise what colonial violence can do to me. To us. I am touched by the vision that Huntley (2020: 62) expresses - that all of the 'work around MMIWG $2 \mathrm{~S}$ must be founded in ceremony and work with spirittaking direction from the sisters on the other side'.

In our work in Palestine, we ask: How can we take direction from our women frontliners, our living and our dead? Our colonised gendered selves who maintain the rhythm towards wholeness, towards life, despite all the odds? I (Hana) know that I, an unafraid Palestinian woman in struggle, have to live into the answers. And to do so, I need an emotion strategy. We strive to bring this emotion strategy forth into our practices and structures of our Palestinian RRC, especially in the supervision and support of the CHWs in the refugee camps. Our relational work is emotional and corporeal. It is rhythmic understanding seasons, ebbs and flows. This is adaptation lived, not out of choice, but survival. Transformative justice is that unique rhythm that skillfully puts into practice the 'nuanced understanding of organizing around trauma' (Dixon, 2020: 22).

1 The speech is available at: www.youtube.com/watch?v=AqyDdHDomtk. The sentence cited begins seven minutes and forty-nine seconds into the speech. 
As Dixon (2020: 23) highlights, transformative justice work requires that we change our structures and 'cultures of judgment'. As oppressed groups rising, when we work against systems of colonial violence that are so deeply racialised, gendered, sexed and classed, our transformative strategies are always a negotiation because all our options bring promises of additional harm. This is why Dixon (2020: 25) emphasises that "[e]ven as we act urgently to resist the state violence that is killing our communities, we must also do slow work to develop community safety and resilience'. Part of changing the structures and 'cultures of judgment' requires us to lead with radical love and to resist the internalisation that people are disposable.

In our Palestinian RRC, for example, we challenge the notion that we 'throw' people away when difficulties arise. On the contrary, we try to engage counter-practices and counter-narratives that uplift our central organising principle that no one is dispensable. We need to begin investing in one another more intensively and intentionally, and to put into practice how we want to be treated. We invest in this process by asking each other questions such as: How do we avoid replicating punitive and carceral logics? How do we resist upholding the idea that people can be rendered disposable? What does it look like for us to create transformative paths towards wholeness for not only ourselves as Palestinians, but also for Israelis, for United Statesians or for anyone else caught up within this settler colonial system of domination - even those Palestinians among us who are actively endorsing racist/patriarchal/classist ways of being and relating?

We believe, consistent with transformative justice praxis, that, when we organise into the answers to these difficult questions, we must guard our dignity at every turn. This means that, when we as Palestinians are actively exploring our role in creating a transformative path towards wholeness for the people that oppress us (such as individuals, collectives and structures that enact colonial oppression), we refuse to swallow our pain and we refuse to ignore the centrality of settler colonial domination in our lives. Transformative justice approaches emphasise that power imbalances in conflicts need to be at the core of any strategy for safety and growth (Bonsu, 2020). In other words, even though a critical component to radical love is that no one is considered disposable and all humans deserve a transformative path towards wholeness - even the most oppressive and harmful to us and among us - the growth and transformation of the people and systems that create and perpetuate harm should never be at the expense of our own opportunities for safety, dignity and self-determination as the people on the frontlines challenging those oppressions head on (Bonsu, 2020). 
For example, a Palestinian mental health worker who was a participant in my (Hana's) dissertation research in Palestine explained that he quit his job because he campaigned against having a team of Israeli psychologists come into his community and train people on family trauma. This example reflects the colonial tensions and the participant's belief that NGOs and related stakeholders too often hide oppressions behind 'neutral' or 'apolitical' solutions. In the participant's own words:

Let me tell you why I resigned from the [name of an international NGO]. First of all, we live in the Palestinian territory of Occupied East Jerusalem, meaning we receive educational, medical treatments by Israelis, and we have no problem with that. But all of the sudden, a series of trainings and family therapy workshops were brought to us with the demand to take these trainings from an Israeli psychologist. In [name of an international NGO], our target population was Palestinian ex-detainees, after they are released and finish their detention sentences, and during their sentences we also work with their families, their children and their close friends. So, it's a very sensitive issue, and I can't fathom how [name of an international NGO] thought it would be helpful for an Israeli psychologist to come and teach us how to intervene/ facilitate family therapy under these circumstances.

The participant is now working as a taxi driver, and he expressed deeply missing the work he was doing before with detainees and their families. However, he decided to draw the line and stand up for what he believes in because the colonial tensions in the NGOs became too oppressive. Israeli professionals may be able to provide helpful tools and models to Palestinian mental health workers. The participant in this research was clear that he held no objection to such exchanges with Israelis. But these exchanges must occur in ways that challenge the relations between the knower 'coloniser' and the object 'colonised'. The participant went on to explain his decolonial analysis and opposition:

Why?! Because I am not a neutral person! I keep my own knowledge of my people. I refuse to have an Israeli teach me about family therapy on how to work with a martyr's mother. So, we asked why trainings by an Israeli in this way? The answer, from the NGO, was because we are neutral and can bring in any professionals, Israeli or Palestinian professionals ... we didn't want to engage in these policies, it was just too much ... so I resigned.

The training by the team of Israeli professionals imposed on the Palestinian mental workers by the international NGO was understood by this participant as an attempt to disconnect him from his own community and devalue his lived experiences. Attempts to devalue this knowledge of his people is a type of 
colonial violence in itself. His refusal to accept this was a decolonial enactment of adaptation and resilience. Transformative justice is about holding accountable the people who are actively involved in upholding systems that cause harm. And this brings struggle. We do not underestimate the daily state of siege of Palestinians living under occupation, and we see the everyday refusal that this Palestinian participant enacted as a critical practice and a powerful example of the need for transformative justice praxis in Palestine to be more rigorously engaged.

\section{CONCLUSION}

Decolonial enactments of adaptation and resilience in Palestine require that we courageously and collectively perform our fully human subjectivities across relations and movements for healing, justice and peace. The multiplicity of frontlines of colonial oppressions in the everyday lives of Palestinians make complex and layered wounds in our bodies, minds, relations, communities and lands through deeply embodied pathways (Atallah, 2017; Giacaman, 2018; Shalhoub-Kevorkian, 2016). Consequently, rather than refer to transitional justice, in this chapter we have argued that adaptation and resilience in Palestine require transformative justice paradigms and practices, which powerfully underscore the need for complex, collective struggles that can challenge the embodied, relational, racialised, interpersonal, intrapersonal and intergenerational expressions of harm. Being condemned to remain under settler colonial occupation into unknown futures requires our constant (re)envisioning of decolonial potentials and radical possibilities.

In this chapter, we shared perspectives and counter-stories grounded in our radical reflecting and 'dream practice' that we engaged in to explicitly and collectively articulate the just futures that we are struggling to work into reality. This includes our reflecting on how Palestinians engage in counter-hegemonic reclaiming and practising of humanity each and every day in our relationships and in our coalitions. Furthermore, in this chapter, we have shown how attempts at abolishing dehumanisation and reclaiming our humanity within everyday enactments of adaptation and resilience are complex and messy, are symbolic and practical, are material and metaphorical, are temporal and spatial and are everything in-between (Shalhoub-Kevorkian, 2016). This praxis works to re-envision possible futures. This re-envisioning is abolitionist - it requires an end. Transformative justice pushes towards the end of the pressure of the coloniser upon the necks of the colonised. No reforms or transitions are necessary. Just as slavery will never require reform, colonialism does not either. They both require abolition. This is transformative justice in Palestine. 


\section{REFERENCES}

Ahmed, S. (2012). On Being Included: Racism and Diversity in Institutional Life. Durham, NC: Duke University Press.

Atallah, D. G. (2017). A community-based qualitative study of intergenerational resilience with Palestinian refugee families facing structural violence and historical trauma. Transcultural Psychiatry, 54, 357-383.

Atallah, D. G. (2021). Decolonial enactments of human resilience: Stories of Palestinian families from beyond the Wall. In M. Ungar (ed.), Multisystemic resilience: Adaptation and Transformation in Contexts of Change. New York: Oxford University Press, pp. 565-583.

Atallah, D. G., Bacigalupe, G. and Repetto, P. (2019). Centering at the margins: Critical community resilience praxis. Journal of Humanistic Psychology, https://doi .org/10.1177\%2Foo22167818825305

Atallah, D. G., Shapiro, E. R., Al-Azraq, N., Qaisi, Y. and Suyemoto, K. L. (2018). Decolonizing qualitative research through transformative community engagement: Critical investigation of resilience with Palestinian refugees in the West Bank. Qualitative Research in Psychology, 15(4), 489-519.

Atallah, D., Kramer, S., Al Bast, L., Stanley, B., Scales, D., Jawabreh, N., Alazzah, S., Abu Srour, M., Abedrabbu, H., Louis, H., Abu Srour, R., Alazzah, S., Al Mashakhah, M., Darwish, M., Ewise, A., Rumi, M. and Wispelwey, B. (2019). Community health work under occupation: Towards the development of a new model to address social and political determinants of health in Palestinian refugee camps. CHW Central. https://chwcentral.org/communityhealth-work-under-occupation-towards-the-development-of-a-new-model-to-addresssocial-and-political-determinants-of-health-in-palestinian-refugee-camps/

Atallah, D. G. and Ungar, M. (2020). Indigenous groups facing environmental racism: Human rights, resilience, and resistance in Palestinian communities of the West Bank and the Mapuche of Chile. In P. Hagenaars, M. Plavsic, N. Sveaass, U. Wagner and T. Wainwright (eds.), Human Rights Education for Psychologists. New York: Routledge, pp. 193-206.

Atallah, D. G. and Dutta, U. (2021). 'Creatively in coalition' from Palestine to India: Weaving stories of refusal and community as decolonial praxis. Journal of Social Issues, https://doi.org/10.1111/josi.12460.

Biko, S. (1978). I Write What I Like. London: The Bowerdean Press.

Bonsu, J. E. (2020). Excerpt from 'Black Queer Feminism as Praxis'. In E. Dixon and L. L. Piepzna-Samarasinha (eds.), Beyond Survival: Strategies and Stories from the Transformative Justice Movement. Chico: AK Press, pp. 49-54.

Brown, A. M. (2017). Emergent Strategy: Shaping Change, Changing Worlds. Chico: AK Press.

Cacho, L. M. (2012). Social Death: Racialized Rightlessness and the Criminalization of the Unprotected, Vol. 7. New York: New York University Press.

Da Silva, D. F. (2009). No-bodies: Law, raciality and violence. Griffith Law Review, 18, $212-236$.

de Coning, C. (2018). Adaptive peacebuilding. International Affairs, 94(2), 301-317. 
Dixon, E. (2020). Building community safety. In E. Dixon and L. L. PiepznaSamarasinha (eds.), Beyond Survival: Strategies and Stories from the Transformative Justice Movement. Chico, CA: AK Press, pp. 15-26.

Dixon, E. (2020). I would like to return my TJ process. In E. Dixon and L. L. PiepznaSamarasinha (eds.), Beyond Survival: Strategies and Stories from the Transformative Justice Movement. Chico: AK Press, pp. 205-208.

Dixon, E. and Piepzna-Samarasinha, L. L. (eds.) (2020). Beyond Survival: Strategies and Stories from the Transformative Justice Movement. Chico: AK Press.

Dutta, U. (2016). Prioritizing the local in an era of globalization: A proposal for decentering community psychology. American Joumal of Community Psychology, 58(3-4), 329-338.

Dutta, U. (2018). Decolonizing 'community' in community psychology. American Journal of Community Psychology, 62(3-4), 272-282.

Evans, M. (2016). Structural violence, socioeconomic rights and transformative justice. Journal of Human Rights, 15(1), 1-20.

Fanon, F. (1963). The Wretched of the Earth. New York: Grove Press.

Fernández, J. S. (2018). Toward an ethical reflective practice of a theory in the flesh: Embodied subjectivities in a youth participatory action research mural project. American Journal of Community Psychology, 62, 221-232.

Giacaman, R. (2018). Reframing public health in wartime: From the biomedical model to the 'Wounds Inside'. Journal of Palestine Studies, 47(2), 9-27.

Gready, P. and Robins, S. (2014). From transitional to transformative justice: A new agenda for practice. International Journal of Transitional Justice, 8(3), 339-361.

Holmes, O. and Balousha, H. (2019). Gaza's generation blockade: Young lives in the 'world's largest prison'. The Guardian. www.theguardian.com/world/2019/mar/12/gener ation-blockade-gaza-young-palestinians-who-cannot-leave (accessed 12 February 2021).

Hooks, B. (2001). All about Love: New Visions. Harper Perennial.

Huntley, A. (2015). Meet Audrey Huntley, Canada. Nobel Women's Initiative. https:// nobelwomensinitiative.org/meet-audrey-huntley-canada/ (accessed 14 May 2020).

Huntley, A. (2020). From breaking silence to community control. In E. Dixon and L. L. Piepzna-Samarasinha (eds.), Beyond Survival: Strategies and Stories from the Transformative Justice Movement. Chico: AK Press, pp. 55-66.

International Center for Transitional Justice. (2019). On solid ground: Building sustainable peace and development after massive human rights violations - Report of the Working Group on Transitional Justice and SDG16+. Retrieved from: www .ictj.org/sites/default/files/ICTJ_Report_WG-TJ-SDG16\%2B_2019_Web.pdf (accessed 3 September 2020).

Kaba, M. and Hassan, S. (2019). Fumbling Towards Repair: A Workbook for Community Accountability Facilitators. Chicago, IL: Project NIA and Just Practice.

Long, E. (2020). Vent Diagrams as healing practice. In E. Dixon and L. L. PiepznaSamarasinha (eds.), Beyond Survival: Strategies and Stories from the Transformative Justice Movement. Chico: AK Press, pp. 209-220.

Lorde, A. (1984). Sister Outsider: Essays and Speeches. Berkeley: Crossing Press.

Lugones, M. (2010). Toward a decolonial feminism. Hypatia, 25(4), 742-759.

Maldonado-Torres, N. (2007). On the coloniality of being. Cultural Studies, 21(2), 240-270.

Masud, H. R. (2019). NGOs Embodying Decoloniality: Towards Emancipatory Psychological Practice and Pedagogy in Palestine (dissertations). https://digitalcom mons.nl.edu/diss/418/ (accessed 9 July 2020). 
Moraga, C. and Anzaldúa, G. (eds.) (2015). This Bridge Called my Back: Writings by Radical Women of Color, $4^{\text {th }}$ ed. Albany, NY: SUNY Press.

Said, E. (1984). Permission to narrate. Journal of Palestine Studies, 13(3), 27-48.

Shalhoub-Kevorkian, N. (2009). Militarization and Violence Against Women in Conflict Zones in the Middle East: A Palestinian Case-Study. New York: Cambridge University Press.

Shalhoub-Kevorkian, N. (2016). The occupation of the senses: The prosthetic and aesthetic of state terror. British Journal of Criminology, 57, 1279-1300.

Shervington, D. (2018). Healing is the Revolution. New Orleans: Institute of Women \& Ethnic Studies.

Shank, A. A. (2020). Beyond firing. In E. Dixon and L. L. Piepzna-Samarasinha (eds.), Beyond Survival: Strategies and Stories from the Transformative Justice Movement. Chico: AK Press, pp. 27-42.

Shara, N. (2020). Facing shame. In E. Dixon and L. L. Piepzna-Samarasinha (eds.), Beyond Survival: Strategies and Stories from the Transformative Justice Movement. Chico: AK Press, pp. 221-232.

Shunnarah, M. (2019). Where is the old country? In I. Khalidi (ed.), The Palestine Issue: Prose, Poetry, and Art Exploring Arab America. St. Paul, MN: Mizna, Inc., pp. 55-6o. United Nations. (2010). Guidance Note of the Secretary-General: United Nations Approach to Transitional Justice. www.un.org/ruleoflaw/files/TJ_Guidance_Note_ March_2010FINAL.pdf (accessed 11 May 2020).

West, C. (2018). Colin Kaepernick: Hutchins Center Honors - W. E. B. Du Bois Medal Ceremony. www.youtube.com/watch?v=AqyDdHDomtk (accessed 18 June 2020).

Wynter, S. and McKittrick, K. (2015). Unparalleled catastrophe for our species. In K. McKittrick (ed.), Sylvia Wynter: On Being Human as Praxis. Durham, NC: Duke University Press, pp. 9-89. 